\title{
USE OF THE LIDAR COMBINED FOREST INVENTORY IN THE ESTIMATION OF SAMPLE TREES HEIGHT
}

\author{
Antons Seleznovs, Ingus Smits, Dagnis Dubrovskis \\ Latvia University of Life Sciences and Technologies, Latvia \\ anton.se1008@gmail.com
}

\begin{abstract}
Precision of the forest inventory planning is still one of the most important problems in the forestry nowadays. The aim of this research was to estimate the sample tree height results of the combined forest inventory (LiDAR CFI) and LiDAR (Light Identification Detection and Ranging) height data by calculating an average value from sample tree neighboring pixel values in the ripening Scotch pine forest stands, comparing the results with the measurements of the height in the area. For the update of LiDAR calculated data and LiDAR CFI height results, the increment algorithms of the Latvian State Forest Research Institute 'Silava' were used, comparing the results with the sample plot measurements. Both results showed a close correlation - in the case of LiDAR CFI with $\mathrm{R}^{2}=0.82$, LiDAR data with $\mathrm{R}^{2}=0.93$, demonstrating a standard deviation: 2.40 and 2.75 , accordingly and standard error: 0.11 and 0.13 , accordingly. The results indicate that both technologies can be used in the forest management, offering reliable information about the forest inventory. Positive values were reached by minimizing the human error factor, which is problematic for the field inventory.
\end{abstract}

Key words: LiDAR, forest management, increment algorithms, tree height.

\section{Introduction}

One of the main tasks of the remote sensing is to develop accurate inventory and planning in the forest management. Technology allows analyzing the forest stands thoroughly, minimizing the human error factor (Dubrovskis et al., 2017). The previous researches were connected with the identification of the tree species and growing stock volume comparison, using both LiDAR technology, harvester production data and forest inventory sample tables. The best result demonstrated the connection between harvester product data and LiDAR data (Seleznovs et al., 2018). The study focused on the estimation and analysis of one of the most important forest inventory factors - the tree height. To complete the task, three data sources were chosen: LiDAR, based on the group of pixels with the calculated from neighboring pixels an average value for the sample tree height; LiDAR CFI, based on a combination of orthophoto and near infrared (NIR) data, and terrestrial measured heights of the sample trees. The results of this study can be attractive for the forest management companies, where the Scotch pine (Pinus sylvestris) is the dominating tree species. Previous studies have showed that the identification of forest inventory factors demonstrates better results in one-storey forest stands, and first of all in monocultures (Kulla, Sačkov, \&Juriš, 2016). According to the inventory data, evenaged forest stands dominate in Latvia, and the last decades demonstrate the growth of the areas with the uneven-aged tree stands (www.geo.lu.lv). The use of LiDAR in these tree stands also demonstrates a good possibility for tree height identification; as the problems are common in the identification of the trees from the understorey (Brovkina, Zemek, \& Fabiánek, 2015). The problems with the identification of tree height could also be caused by brushwood and relief specifics, where the laser beams cannot identify the tree stem beginning. This study will prove the tree height in the forest stands without brushwood and understorey. The aim of this research is an estimation of the sample tree height results taken from the combined forest inventory (LiDAR CFI) and LiDAR (Light Identification Detection and Ranging) height data by calculating an average value from the sample tree's neighboring pixel values and comparing the results with the measured heights.

\section{Materials and Methods \\ Study area}

The study was completed in Riga municipalityowned forest, to the east from the capital city of Latvia, in the Jugla district of Gauja forest department (Figure 1). For the study, the ripening Scotch pine tree stands in the fifth age class (81-100 years) were chosen. Scotch pine monocultures dominated the whole study area. For the study we created 30 sample plots with a radius of $12.62 \mathrm{~m}$ and an area of 500 $\mathrm{m}^{2}$. In the sample plots, all trees with the height of more than $12 \mathrm{~m}$ were measured. In total, the height of 455 trees growing in the sample plots were measured. The sample plot centers were marked using the 'QGIS' software. In the terrestrial research, the field computer 'Algiz 8X' was used. For the height measurements, the instrument Vertex Laser Geo was used. The middle of the sample plot was marked with the Vertex tripod, measuring the distance to the trees and their azimuth. Following formulas were used for the calculation of tree coordinates:

$$
\begin{aligned}
& \Delta X=\text { distance } \times \cos \alpha \\
& \Delta Y=\text { distance } \times \sin \alpha \\
& \mathrm{X}=\mathrm{X}_{0}+\Delta X
\end{aligned}
$$




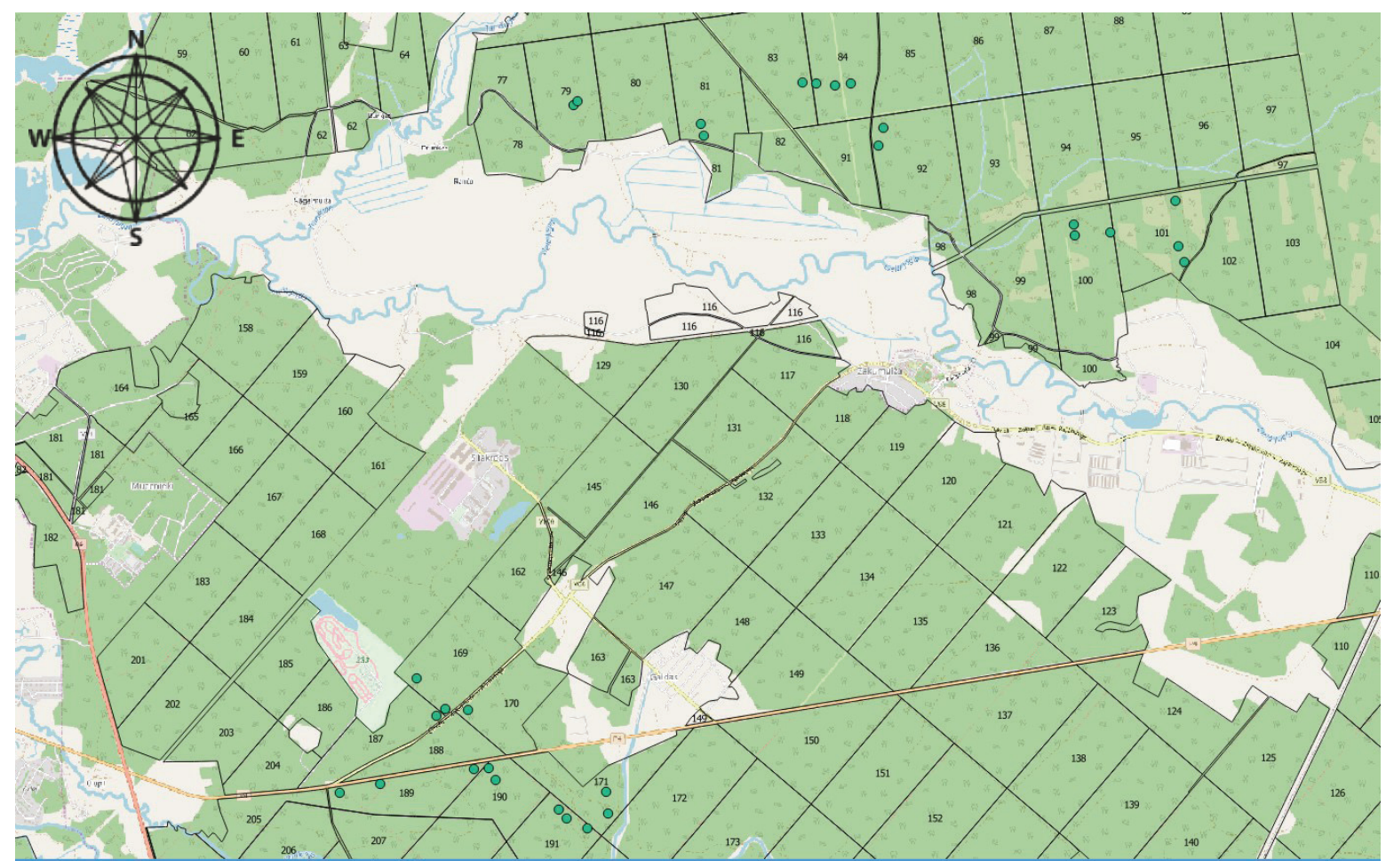

Figure 1. Allocation of study sample plots.

LiDAR data processing

$$
\mathrm{Y}=\mathrm{Y}_{0}+\Delta Y
$$

where $\mathrm{X}_{0}$ and $\mathrm{Y}_{\mathrm{o}}$ are the coordinates of sample plot center. The angle value was converted from degrees to radians using Microsoft Excel program.

The basis of the LiDAR data for this study were scanned in the years 2013-2014 by the Latvian Geospatial Information Agency (LGIA) in Gauja forest department areas. Data was summarized as a group of pixels, representing the height value of the trees in a forest stand. To develop the precision of the LiDAR data value, it was decided to take the nearest pixels from the tree location, counting an average value of a concrete tree height. The second way in this study for counting of the tree heights was the use of the LiDAR CFI method, which is based on LiDAR data, orthophoto and near infrared (NIR) images. According to this method, the height of a tree is a local maximum calculated from the height values. For this aim the tree centers with the concrete parameters were chosen, based on LiDAR and NIR data (Table 1).

After the calculation of these parameters, the results were saved in the 'las' format. After the noise removal, LiDAR data processing followed. For this aim, in this study we used the Gauss matrix. Obtained from the matrix, the highest points of trees and distance to the terrain were registered as a tree height. For better results, interpretation identified the LiDAR points, which belong to a concrete tree. For

Primary processing of LiDAR and NIR data

\begin{tabular}{|l|l|l|}
\hline \multicolumn{1}{|c|}{ Group of data } & \multicolumn{1}{|c|}{ Name of parameter } & \multicolumn{1}{c|}{ Description } \\
\hline NIR & Position of sample tree center & \multicolumn{1}{|c|}{$\times$} \\
\hline & h, e, i & Texture indicators, defined in accepted radius around a tree center \\
\hline \multirow{4}{*}{ LiDAR } & nir & Value of NIR channel \\
\cline { 2 - 3 } & Position of sample tree center & \\
\cline { 2 - 3 } & h & Sample tree height \\
\cline { 2 - 3 } & Slope & Slope coefficient of crown top \\
\cline { 2 - 3 } & Z_avg, z_sigma & Center indicators of foliage mass \\
\cline { 2 - 3 } & evp, vp, vpa & Dimension of tree crowns \\
\cline { 2 - 3 } & ntc, ntr, vpa & Neighboring tree interaction indicators \\
\cline { 2 - 3 } & histogram & Tree point vertical bar chart \\
\hline
\end{tabular}


the creation of a tree model, the points within a radius of $6 \mathrm{~m}$ from the crown top were used. NIR data helped to identify the sample trees. The result of NIR data quality depends on the quality of aero photo and size of pixels. During the tree identification process there are following phases: preparing and processing of the photo, and summarizing of the results. The photos have strict geographical binding and are cut into smaller photos. Sizes of the photo were based on the power of number 2. Fourier transform helped to develop the distinct model of the tree stand. Consequently, the information contained the LiDAR and photo data as well as sample tree location. This method was created in a cooperation between the Latvia University of Life Sciences and Technologies and the company 'Metrum'.

\section{Increment algorithms}

Created in the Latvian State Forest Research Institute 'Silava' by researching thenational forest inventory monitoring, the algorithms are suitable for five tree species of Latvia, including the Scotch pine (Donis, 2014). Algorithms are based on the calculated variable coefficients for each tree species, the tree age and the previously measured height:

$$
\begin{aligned}
& H_{2}=1.3+\frac{A_{2}^{b_{1}}}{b_{2}+100 \times b_{3} X_{0}+X_{0} A_{2}^{b_{1}}} \\
& X_{0}=\frac{\frac{A_{1}^{b_{1}}}{H_{1}-1.3}-b_{2}}{100 \times b_{3}+A_{1}^{b_{1}}}
\end{aligned}
$$

where: $A_{1}$ - breast height age at the first measurement (ages); $\mathrm{A}_{2}$ - breast height age at the second measurement (ages); $\mathrm{H}_{1}$ - tree height at the period beginning (m); $\mathrm{H}_{2}$ - tree height at the period end (m); $b_{1}, b_{2}, b_{3}$ - empirical coefficients (for the Scotch pine: $\left.b_{1}=1.113 ; b_{2}=-44.224 ; b_{3}=21.107\right) . H_{1}$ taken from LiDAR and LiDAR CFI data.
This formula was used in the update of the LiDAR and LiDAR CFI data, and the result compared with the measured height. The result of breast height age needed the correction in dependence on a forest stands' site index.

Data processing

During the research, the LiDAR and measured data were processed. For processing, the regression analysis was chosen, which was completed in the program $\mathrm{R}$, analyzing the tree height and using one factor analysis. The results are presented in the graphics, showing information about coefficient of determination. Data analysis was completed with a confidence level of $95 \%$.

\section{Results and Discussion}

Comparing the calculated LiDAR and LiDAR CFI data, the results of different tree height demonstrated different correlation. Previous methods compared different data sources of growing stock volume, analyzing the PRD production data, the field data and the LiDAR CFI technology. For the first time, a separate analysis of a tree height in this research was completed in Riga forests. During the research, the results from 30 specially located sample plots were compared, containing the information about the measured tree heights, and the calculated heights from LiDAR CFI data and LiDAR data sources, using increment algorithms. Figure 2 demonstrates the results of comparison of the measured heights to LiDAR CFI data calculated heights using an increment algorithm.

The results show that the determination coefficient is high $-\mathrm{R}^{2}=0.82(\mathrm{p}<0.01)$. The reason for thegood result is the minimization of human error. However, the risk of the human factor can be during the estimation of the trees because of the orthophoto

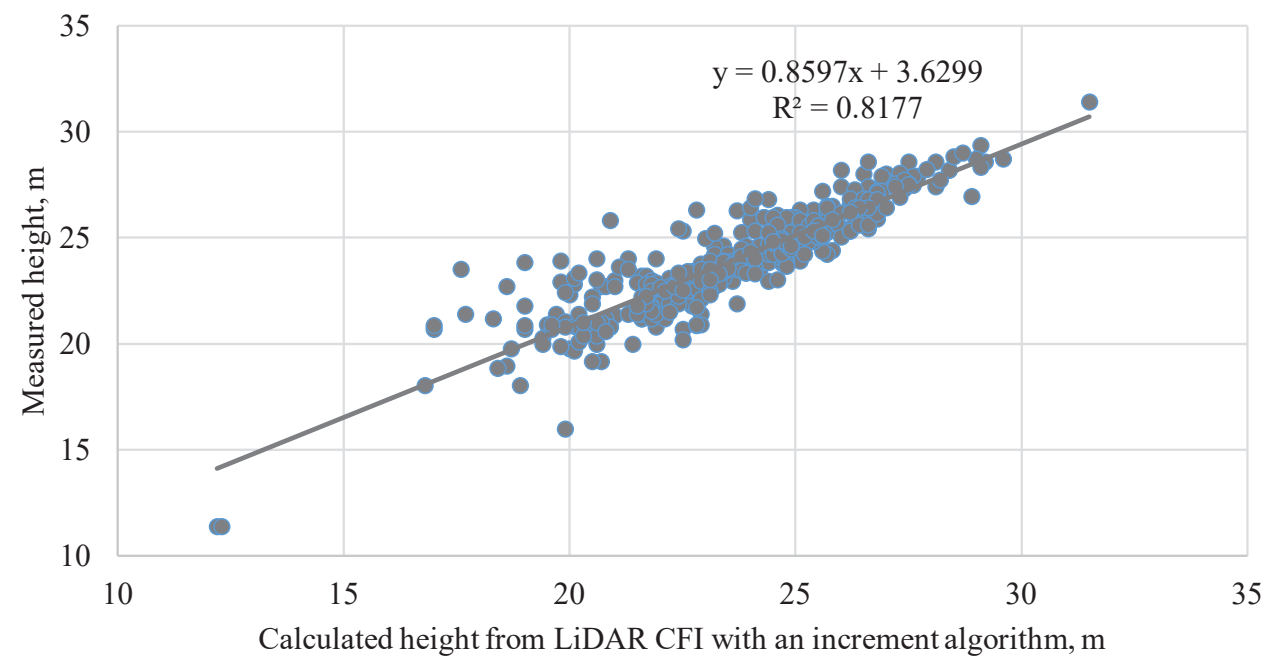

Figure 2. Comparison of measured tree height to calculated height from LiDAR CFI. 


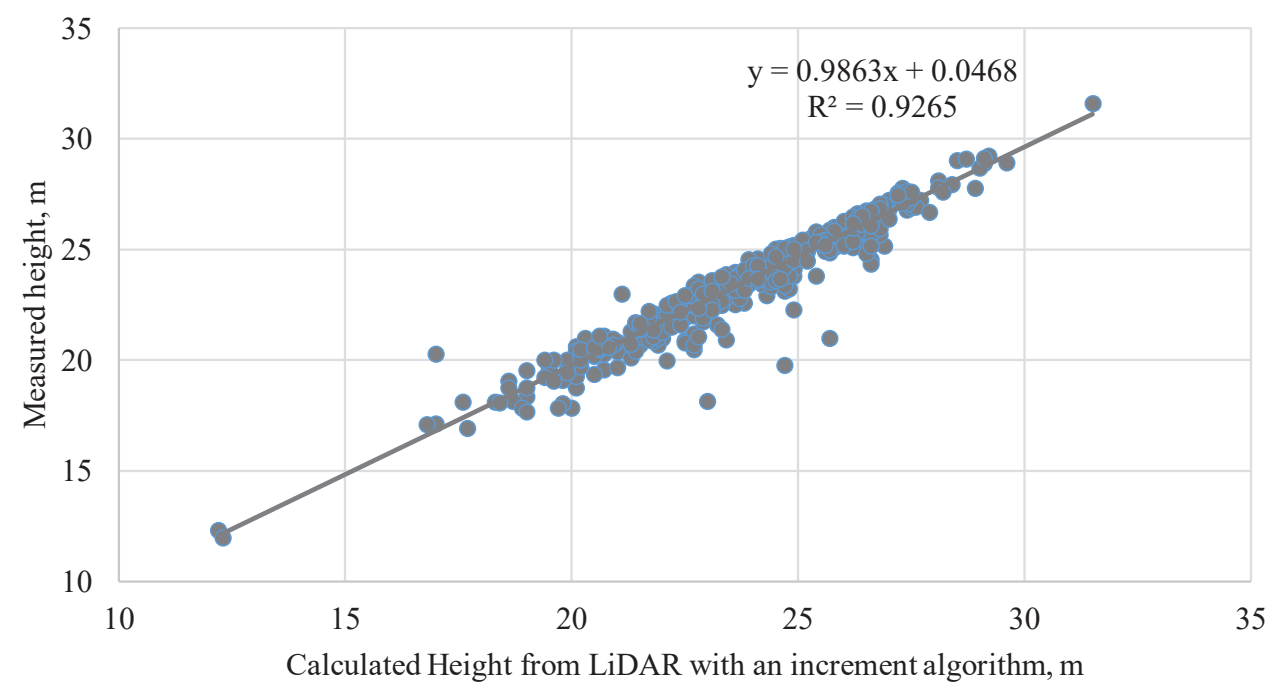

Figure 3. Comparison of measured tree height to calculated height from LiDAR data.

quality and the GPS coordinates errors. This method accepts a tree height as a local maximum, although it can belong to the neighboring trees. Better results were obtained by the comparison of measured height data and calculated height from LiDAR data, given in Figure 3.

The strong correlation can be explained by the minimizing of the human factor in the analysis of the LiDAR data. In this method not only the height value from a coordinate is used, but also the neighboring height values, calculating the mean result as a tree height. By comparing different values, the result is better than in the case of an analysis of the aerial photo and local maximums. One of the most important problems is the accuracy of GPS coordinates, because during the data analysis some of the points were located in the empty areas, where there are no identified growing trees. These points were located nearby to the identified tree groups. Although not straight growing trees were specially marked during data analysis, the identification of the height using CFI method was considerably more difficult than during the height calculation from LiDAR data. This is one of the causes why the LiDAR CFI method is supposed to have a higher risk of the human error. The other reasons are the quality of aerial images, inaccuracy of the coordinates and the amount of analyzed values, because only one value is taken for a height from local maximum instead of analyzing neighboring values.

For this particular study were chosen forests, where in the next 15 years a final felling is planned, that is why reliable information about the forest inventory data is topical for the forest owner. For updating one of the most important inventory data - tree height the increment algorithms were used, which originally came from the national forest inventory monitoring sample plots and for the first time were used in the forest management, highlighting the bright perspectives for the use of these algorithms in the forest management planning. In the case of our study, in plots there were one-storey stands without any brushwood. Evenaged and one-storey forest stands are most suitable for the remote sensing, because of a good terrain and possibility of scrupulous stem analysis (Hancock et al., 2012). In Latvia, the results of LiDAR CFI and LiDAR data processing could definitely be integrated into the forest management forecasting system, providing the probable information about the tree height. In practice it means that $82 \%$ of LiDAR CFI data changes are described by the model and in the case of the LiDAR data processing - even 93\% described by the model. An attractive place of data integration could be the forests nearby Riga, because of their simple structure and high amount of Scotch pine monoculture. The use of the remote sensing and LiDAR technology as well is not disturbed by high amount of tree species, understorey and, as a result, the quality of images allows to analyze the forest virtually, saving the human and time resources (Wulder et al., 2012). In contrast to field inventory, LiDAR technology demonstrates better calculation possibilities of the main forest inventory data, such as growing stock volume and breast height diameter by the thorough analysis of every tree stem, and reducing the mistakes from the yield tables (Mielczarek, Bałazy, \& Zawiła-Niedżwiecki, 2015).

Despite the good results of the technology, one of the most topical questions for the forest inventory remains the analysis of uneven-aged forest stands with a few storeys. The tree identification in these stands is considerably worse than in even-aged monocultures and mixed one-storey forest stands. One of the solutions could be the development of laser scanning technology and another one could be continuation 
of the research in remote sensing area, putting the main emphasis on diameter at breast height, basal area, forest site indexes and tree interrelations in the uneven-aged forest stands. In case of successful research, the forecasting model could help the forest owner in the decision making aspects concerning the forest management planning.

\section{Conclusions}

1. Comparison of LiDAR CFI calculated height with the measured height demonstrated a strong correlation $\left(\mathrm{R}^{2}=0.82\right)$.

2. Calculated height from LiDAR data demonstrated a better correlation $\left(\mathrm{R}^{2}=0.93\right)$.
3. The increment algorithms could be used for height forecasting in the forest management planning, because of the good study results.

4. The use of LiDAR technology in forest management reduces the risk of the subjective factor in the forest inventory, bringing the excellent planning possibilities for the forest owner.

\section{Acknowledgements}

This study was supported by chief forester of Gauja forest department - Andris Upenieks, forest officer Vents Skrodelis and Riga forests' GIS specialist Juris Zarins.

\section{References}

1. Brovkina, O., Zemek, F., \& Fabiánek, T. (2015). Aboveground biomass estimation with airborne hyperspectral and LiDAR data in Tesinske Beskydy Mountains. Beskydy, 8(1), 35-46. DOI: 10.11118/ beskyd201508010035.

2. Donis, J. (2014). Zinātniskā pamatojuma izstrāde informācijas aktualizācijai Meža valsts reǵistrā (Creation of the the scientific substantiation for an information updating in the Forest State Register). Retrieved February 25, 2019, from https:/www.zm.gov.lv/public/ck/files/ZM/mezhi/MAF/ PARSKATS_Informacijas_aktualizacijai_MVR_Silava.pdf. (in Latvian)

3. Dubrovskis, D., Daǵis, S., Šmits, I., Baltmanis, R., \& Krūmiņ̌̌, J. (2017). No tālizpētes tehnoloǵiju datiem iegūtās meža inventarizācijas informācijas pielāgošana LVM mežsaimniecības telpiskās un darbību plānošanas atbalstam (Conformation of forest inventory information from remote sensing to Latvia's State Forests (LVM) spatial planning). Retrieved February 28, 2019, from https://www. lvm.lv/petijumi-un-publikacijas/no-talizpetes-tehnologiju-datiem-iegutas-meza-inventarizacijasinformacijas-pielagosana-lvm-mezsaimniecibas-telpiskas-un-darbibu-planosanas-atbalstam-1-etapastarpatskaite?view=attachments. (in Latvian)

4. Hancock, S., Lewis, P., Foster, M., Disney, M., \& Muller, J.P. (2012). Measuring forests with dual wavelength LiDAR: a simulation study over topography. Agricultural and Forest Meteorology. 161, 123133. DOI: 10.1016/j.agrformet.2012.03.014.

5. Kulla, L., Sačkov, I., \& Juriš, M. (2016). Test of airborne laser scanning ability to refine and streamline growing stock estimations by yield tables in different stand structures. Lesn. Cas. For. J. 62, 39-47. DOI: 10.1515/forj-2016-0005.

6. Mielczarek, M., Bałazy, R., \& Zawiła-Niedżwiecki, T. (2015). Porównanie dokładności zdalnych metod szacowania wysokości drzew (Comparison of the accuracy of remote methods of tree-height estimation). Sylwan. 159(9), 714-721. (in Polish)

7. Seleznovs, A., Dubrovskis, D., Dagis, S., Smits, I., \& Baltmanis, R. (2018). Use of the LiDAR combined forest inventory in the estimation of felling site stocks. Research for Rural Development 2018. 40-46. DOI: 10.22616/rrd.24.2018.006.

8. Wulder, M.A., White, J.C., Nelson, R.F., Naesset, E., Orka Ole, H., Coops, N.C., Hilker, T., Bater, C.W., \& Gobakken, T. (2012). LiDAR sampling for large-area forest characterization: A review. Remote Sensing of Environment 121, 196-209. DOI: 10.1016/j.rse.2012.02.001.

9. Zarins, J., Lukins, M., \& Jansons, J. (2016). Mežaudzes struktūras izmaiņas ūdensteču aizsargjoslās. Meža valsts reǵistrs un meža resursu monitorings (Structural changes in the watercourse protective zone. State Forest Register and National Forest Inventory). Retrieved March 11, 2019, from https://www.geo. lu.lv/fileadmin/user_upload/lu_portal/projekti/gzzf/Konferences/LU_74_zin_konference_A5_F.pdf. (in Latvian) 